-

技術トピックス



\title{
厚板製造における自動操業技術の確立*
}

\author{
柳 沢 忠 昭**.三芳 \\ 純**
}

\section{Development of Full-automated Plate Production System}

Tadaaki Yanazawa and Jun MiYoshi

昭和 51 年 3 月稳動した水帛製鉄所第， 2 原板工場は， 労衝生産性の向上, 品質の向上などをめざして, 生産管 理システム，作業情報システム，自動運転システムの一 元化および各種自動省力機器の開発・樽入をはかり，才 ペレーターの役割を総合監視と異常の処置のみに限定し た，いわゆる「ノーマン・コントロール」化された丁場 である. 現在, 所期の目的どおりの順調な操業がなされ ている.このたび，この「自動操業の確立」に関して， $\lceil$ 昭和 51 年度大河内記念生産特賞」受賞の栄誉に浴し た.ここに，その概要を紹介し，参考に訨したい。

\section{1. 自動操業の必要性}

本来，厚板製造の特質として，注交生産が原則であり また，用途上からも，一品ごとに寸法，仕様が異なつて いる. 往つて，製造面においても，工程管理面に扔いて も，一品一葉単位で処理しなければならず，そのため， 多くの操業要員を投入し，しかも，その熟練された技能 および特有のきめ細い管理に依存する傾向があり，これ が，ホットストリップ工場などに比べて，著しく労働生 産性が劣る主因といえる。このことは，逆に，厚板工場 へのコンピューターや自動省力機器の導入が, 非常に有 効であるといえる，我が国の厚板工場では，各社とも， この点に看目し，これらの開発・導入に積極的に取り組 み，ここ数年間の進歩はめざましいものがある.しかし それらは，いずれも部分的なものであり，未着手部分も 多く，「少ない要貝で，生産能率の高い，安定した操業」 を実現し，究極の目的であるコスト低減を飛躍的にはか るためには，工場全体にわたる自動操業が不可欠のもの である。

\section{$1 \cdot 1$ 生産能率の向上}

この厚板圧延機は表 1 に示すごとく，超层幅の強力か つ高性能なものであり，64" $\phi$ の UO パイプ素材の优 給が可能な，いわゆる，コントロールド・ローリングに 適した压延機である.この能力を最大限有効に使用すれ
ば，従来ミルの 1.5 倍の能率アップとなるが，これらの コントロールは熟練者の限界を越えるものであり，熟練 者特有のきめ細かさを兼ねそなえたコンピューターによ る自動制御によつて，はじめて，ての高能率王延が可能 となる. また，当然のことであるが，压延機の前後設備 である加熱炉周辺および欮断・精整ラインについても， 高能力化・高速化が要求され, 必然的に, 自動操業が不 可久となつてくる．さらにスラブャードから倉庫に至る 七程·納期管理についても，一品一葉のものを多量に精 度よく処理するためには，自動運転システムと有機的に 結びついた管理システムが必要である。

\section{2 省力化}

近年，我が国に技汁る賃金の上昇，労働者不足の傾向 は著しく，製造コストに占める労務費の比率は增大して きており, 特に，厚板工場では，労衝集約的な作業（例 えば，採寸・表示・刻印作業，検査作業，各ヤード管理 作業，ハンドリング作業なご）が多く，これらの手作業 を個々に機械化し，自動化してゆくことによつて，大幅 な省力が可能となる.

\section{3 品 ·歩止の向上, その他}

厚板歩止は，過去 10 年間で約 $10 \%$ の著しい向上が 歹られているが，これは，素材設計をはじめとして，生 延機の制御などに，各社がコンピューターを導入し，追 求してきた成果である。厚板歩止向上の要因として，板 厚精度 (板内および板間) 幅出し精度, 平面形状制御, 温度補正を含めた塑断精度などがあるが，自動操業の確 立による精度向上により，さらに，歩止向上の余地があ 表 1 仕上圧延機仕様

\begin{tabular}{l|l}
\hline ワークロール寸法 & $1200 \mathrm{~mm} \phi \times 5490 \mathrm{~mm}$ \\
ハックアップロール寸法 & $2400 \mathrm{~mm} \phi \times 5390 \mathrm{~mm}$ \\
ハウジング単重 & $380 \mathrm{t}$ \\
主電動機容最 & $8000 \mathrm{~kW} \times 2$ \\
压延速度 & $3.14 / 7.54 \mathrm{~m} / \mathrm{s}$ \\
最大王延压力 & $8000 \mathrm{t}($ 僢時 $10000 \mathrm{t})$ \\
ミル常数 (キスロール) & $1200 \mathrm{t} / \mathrm{mm}$ \\
\hline
\end{tabular}

* 大河内記念生産特賞受賞 昭和 52 年 5 月 12 日受付 (Received May 12, 1977)

** 川畸製鉄 (怢) 水舄製鉄所 (Mizushima Works, Kawasaki Steel Corp., 1 Kawasakidori Mizushima Kurashiki 712) 
る. また，人手作業を機械化，無人化することにより， 人為的な之スの解消, 表示・刻印などの美麗度の向上, 不安全作業の解消などの効果も大きい.

\section{2. 開発の経 緯}

この自動化システムは, 昭和 42 年に稼動した水島第 1 厚板工場において，長年にわたり開発してきたものを 基盤として, 発展・総合化したものである.オーダーエ ントリー処理からはじまり, 素材設計, 工程計画, 品質 情報処理, 出荷処理にいたるまでの生産管理のコンピュ ーター化, ブラウン管表示器 (C R T ) タイプライター キーボードなどをライン各所に配置したリアルタイム作 業情報システムの開発，压延機のコンピューターによる 自動圧延制御および自動板厚制御（A G C) の導入など， いずれも厚板業界では，はじめてのものであり，当時で は画期的なものであつた. その後 10 年間にわたつてこ れらを充実・拡大させ, 省力, 生産能率・品質の改善に 大きく貢献してきた．しかし，作業情報システムが直接 機械を操作するものは，压延機など極く一部分に限られ 基本的には，CRTなどに表示されたリアルタイムの作 業情報をもとに人手により機械を操作するものであつ た. さらに，各種マーキングやラベル貼付をはじめと少 る機械化されていない人手作業が多数存在し, ローラー テーブル，トランスフォー，クレーンなどによるスラブ や鋼板の搬送も，目視による手動操作でおこなわれてお り，理想像であるノーマンコントロールをめざすには， 数段の飛躍が必要であつた。このため，レイアウトや設 備自体も, 全自動操業を前提に設計を進め, すでに開発
されていた技術のレベルアップと，未解決であつた多数 の新規課題の開発，さらに，これらの技術の総合化，信 頼性の向上を強力に推進してゆき，完成するにいたつ た，具体的な計画をはじめてから，完成するまで，わず か 26 ケ月という短期間の建設であつたが，第 1 厚板工 場で蓄積した技術と関係メ一カー各位の努力により，全 自動操業を確立することができた.

\section{3. 自動操業システムについて}

図 1 に第 2 厚板工場のシステム構成を示す。まず，本 社よりオーダーを受理し，素材設計，工程設計をおこな い，製鋼・分塊・厚板の各工場に対して製造命令をだす 生産管理システムがある.つぎにこの命令をうけて，デ ーターハイゥェーを経由し, 各厚板製造現場へ, タイミ ングよく作業実行指令をだすリアルタイム作業情報シス テムがあり，この指令は，現品と同期しており，製造設 備を制御操作しているプロセスコンピューターとリンク されている. これにより，人手を介さず，設備の操作が なされている．また，この作業情報システムは，常に， 各プロセスコンピューターや自動化㙨器から実績情報を 受けていて, 直ちに, 次工程指令一反映させ, 各作業の 状沉変化に対応するとともに，品質管理・工程管理に必 要な情都を生産管理システムにフィードバックしてい る.

これらのシステム群と多数の自動省力機器があいまつ て，全自動操業を構成しており，これがこの工場の特徵 であるが，その代表的なものを以下に紹介する。

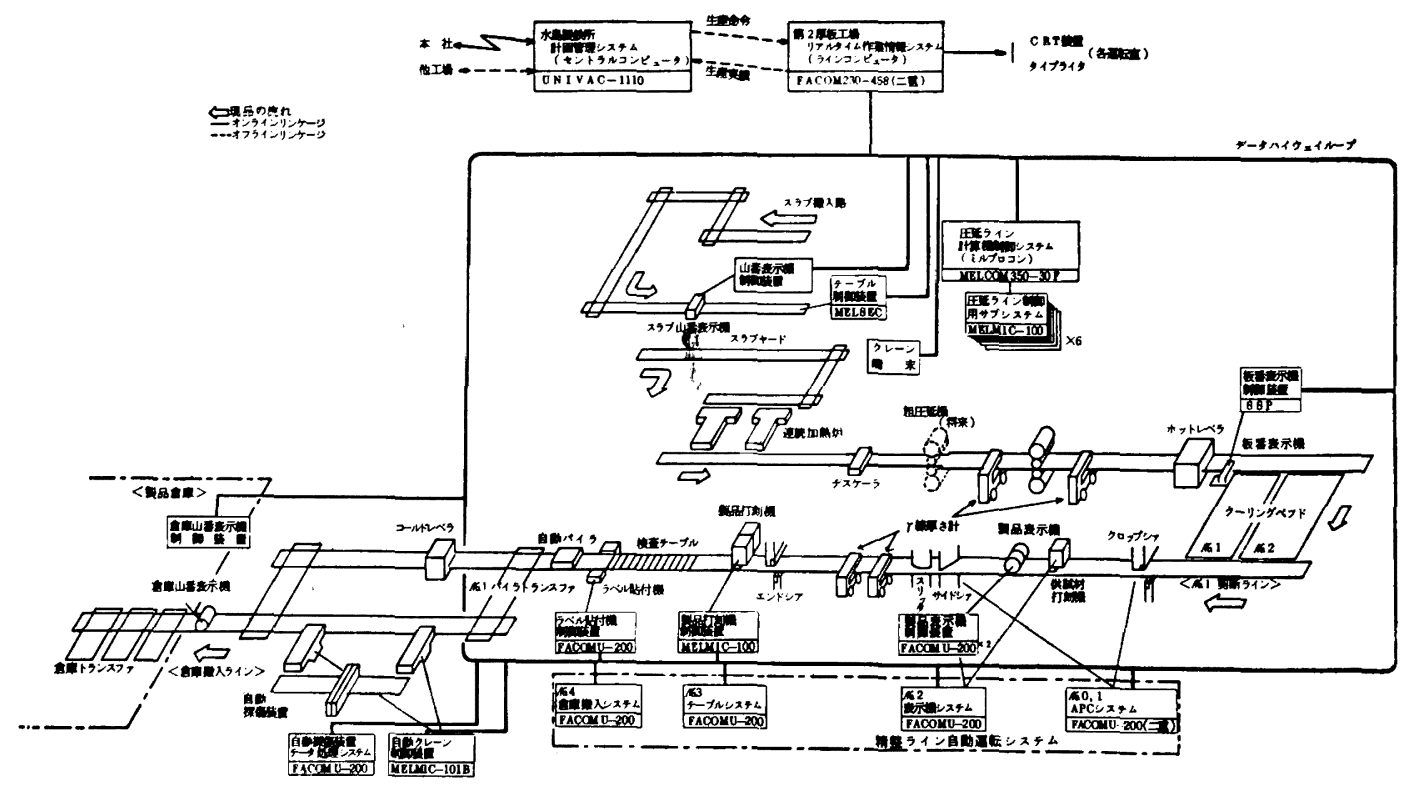

図 1 第 2 厚板工場システム满成困 


\section{1 竘断ライン銅板搬送の完全自動化}

従来, 剪断ラインの自動搬送は, 多数の鋼板検出器を 配列する方式で，試みられてきたが，ラインの一部分に 限られ, しかも, シャーなど機械前後のように, 精度や 能率に影響の大きい個所では，人閒の目視に上る運転の 方がすぐれており，検出器の信頼性にも難があつたため 全ラインの自動搬送化は難かしいものとされていた．第 2 厚板工場では図 2 の概念図に示すごとく, ローラーテ ーブルと直結したパルスシェネレーターからの信号によ り，鋼板の位置を常にコンピューターのメモリー上に記 憶するデシタルトレース方式を開発・実用化した。

$1 \mathrm{~mm} /$ パルスの精度で記憶させ, ラインおのおのの個 所・場面で必要に応じた精度て搬送・停止制御をおこな う, 高精度, 高能率の自動搬送システムである.この方 式の利点として, 要員削隇はもちろんのことであるが, 以下の点を挙げることができる.

（1）精度よく位置検出しているため，テーブル上の 鎆板の間隔をきわめて接近させることができ，ラインの 有効使用が可能となり, また $120 \mathrm{~m} / \min$ という従来の 2 倍の高速搬送が可能となり, 能率が向上する.

（2）コンピューターを使用しているので，他の自動 化システムとの結合が容易である.

（3）オーバーランなどによる鋼板裏面のスリ佌が皆 無である.

（4）タイミングよく，必要な時間だけ，連続的に一 方向のみに作動するので, 電力使用量, 機械のメインテ ナンスの面で有利である.

（5）機能の修正に際して柔軟性がある.

\section{2 省力機器の開発}

省力機器は, 単に能率アップ, 人員削減ばかりでなく 重笳作業, 污れ作業, 単調作業加 5 の開放, 直接, 製品 などに作業しないことによる安全性の向上, 人為的えス の絶减, 明確性の向上, 美麗度の向上などの利点がある. この工場では, 困1に示すごとく, スラブ山番表示譏, ホットレベラーマーキング装置, 測長搬送による採寸作 業の廃止, 供試材打刻譏, 製品表示㙨, 製品打刻機, ラ ベル貼付機, 自動探傷装置, 倉庫山番表示機, サイドシ ャ一端板絬束装置などが開発, 導入されている.これら はすべて，今回，新規に開発されたものではないが，処 理能率, コンピューターとのリンヶージ, 信頼性などの 面で，大幅に改良され，全自動操業に大きな役割を揀し ている.

\section{$3 \cdot 3$ 圧延機形状制御}

圧延機の計算機制御については, 昭和 42 年第 1 厚板 工場に導入されて以来, 幾多の改良がなされ，実用化さ れているが，今回は，ロールの熱膨張や摩耗，压延中の 鋼板の形状なども制御モデルに組み込み，より精度の高 いものになつている.さらに，一般的におこなわれてい るクラウン比率一定の原則にもとうくくパススケシュール

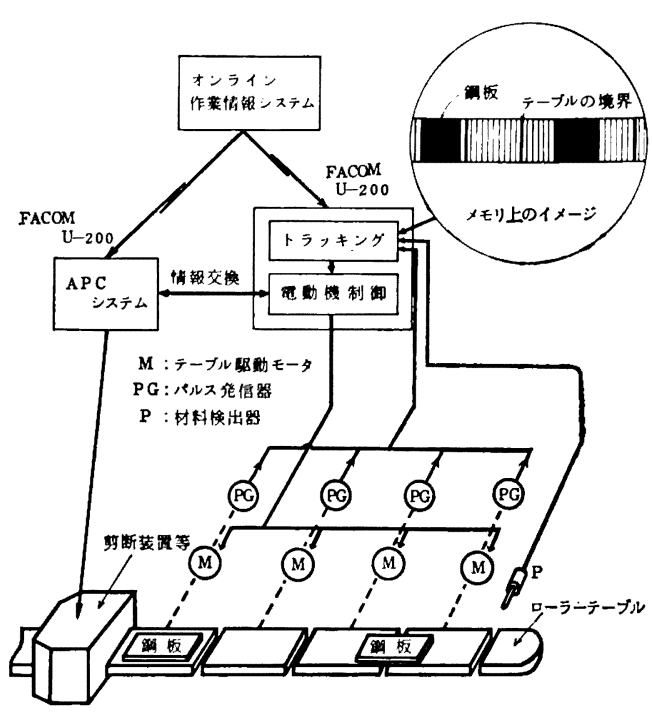

図 2 穷断ラインの全自動鋼板搬送



図 3 パススケジュール決定方式

決定方式ではなく，図 3 に示すような形状制御段階での 途中パスを最大にとることのできる決定方式を開発・笑 用化した，その結果，高能率でしかも，プレートクラウ ンの小さい鋼板の压延が可能となつた。

\section{4 ヤードの自動管理}

スラブヤード，製品倉庫ヤードをはじめとして，各ヤ 一ドの工程币の鋼板の管理は，一品一葉管理の必要な厚 板工場にとつて，重要であり，このために，ハンドリン グや置場管理に多数の要員が必要であり，また，管理精 度にも限界があつた。梁 2 厚板工場では，これらのヤ一 ド管理をリアルタイム作業情報システムの管理下におき 最も適正な置き場をコンピューターで決定し，マーキン グ装置や，自動制御されているおの扮のの機械と有機的 に結合させる方式とした．これにより，要員削减，有効 使用によるヤード面稓の縮少などが可能となつた．また 一品一葉の管理が正確に迅速になされているたい，より 精度の高い納期管理，工程管理となつている。 


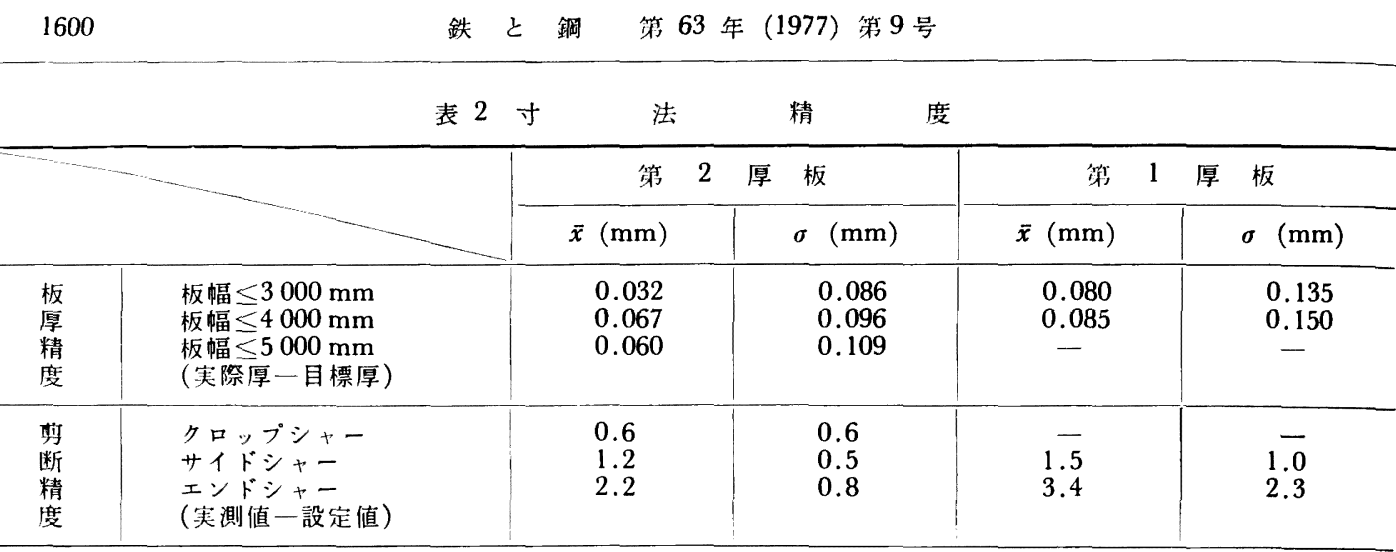

表 3 注文歩 止推移

\begin{tabular}{rr|r}
\hline 昭和 52 年 1 月 & $90.6 \%$ \\
& 2 月 & $90.4 \%$ \\
3 & 月 & $91.0 \%$ \\
\hline
\end{tabular}

注) 注文步止 $=\frac{\text { 全 } 1 \text { 级製品重量 }}{\text { 全素材重量 }}$

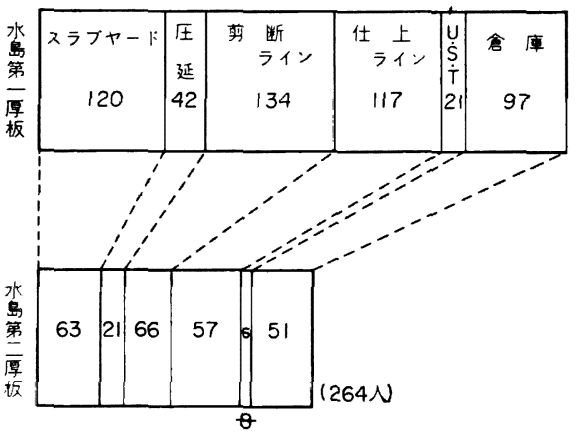

拄）協力会社を含打直接作業員（3直）第１厚板は第 2 厚板箱囲で の 3 直煥算值

図 4 操菜要員比較

\section{4. 操 業 状 況}

稼動後 1 年余経過しているが, オイルショック以来の 不況による需要減により，いまだフル操業していないの でその真価を十分発揮するまでに至つていないが，最近 の実績を招介する.

\section{$4 \cdot 1$ 操業要員}

図 4 に示すごとく，第１厚板工場に比べて，約 $50 \%$ の要員で操業しており, 全自動操業の著しい成果である.

\section{2 寸法精度の向上}

表 2 に最近の圧延・剪断の寸法精度を示す. バラッキ の少ないのが特徵である.

\section{3 歩止の向上}

精度の向上および不合格率の低隇により, 表 3 に示す ように, 注交歩止も高いレベルにある. 品種構成により 変動はあるが 3 月の $91.0 \%$ は現時点で世界最高の值で ある・

以上に，全自動操業のあらましを述べたが，この確立 した技術を基盤として，さらに高水準のレベルアップ項 目がみいだされつつあり, いま以上の成績向上が期待で きる。 